\title{
Advertising, Brand Capital, and Asset Returns*
}

\author{
Frederico Belo ${ }^{\dagger} \quad$ Xiaoji Lin ${ }^{\ddagger} \quad$ Maria Ana Vitorino ${ }^{\S}$
}

February 13, 2011

\begin{abstract}
We provide a theoretical and empirical analysis of the link between advertising expenditures, brand capital, and asset returns in the cross-section of U.S. publicly traded firms. Interpreting advertising expenditures as firms' investment in brand capital, we document that: (i) firms with high brand capital investment rates underperform firms with low brand capital investment rates by $7 \%$ per annum; and (ii) brand capital intensive firms outperform low brand capital intensive firms by $4.1 \%$ per annum. Based on standard Q-theory of investment, we develop a structural dynamic investment-based model in which advertising expenditures and firm's risk are both jointly and endogenously determined. The model replicates the empirical asset pricing facts reasonably well. In addition, the model is consistent with the timeseries properties of brand capital and physical capital investment rates, as well as with the unusually high advertising expenditures during seasoned equity offerings. Taken together, our results suggest that standard Q-theory of investment provides a useful framework for understanding the dynamics of advertising expenditures by corporations.
\end{abstract}

JEL Classification: G12, E32

Keywords: Brand Capital, Cross-Section of Stock Returns, Q-theory

\footnotetext{
${ }^{*}$ We thank François Gourio for helpful discussions and to seminar participants at the 2010 Marketing Science conference, University of Minnesota and London School of Economics for comments. We thank the research support from the Rodney L. White Center for Financial Research at the University of Pennsylvania. All errors are our own.

${ }^{\dagger}$ Finance Department, Carlson School of Management, University of Minnesota, 3-137 CarlSMgmt, 321 19th Avenue South, Minneapolis MN 55455. Tel: (612) 626-7813 and e-mail: fbelo@umn.edu.

${ }^{\ddagger}$ Finance Department, The London School of Economics and Political Science, Houghton Street, London WC2A 2AE, United Kingdom. e-mail: X.Lin6@lse.ac.uk

$\S$ Marketing Department, The Wharton School, University of Pennsylvania, Ste. 700 JMHH, 3730 Walnut Street, Philadelphia, PA 19104 U.S.A. Telephone: 215-746-2369 E-Mail: vitorino@wharton.upenn.edu
} 


\section{Introduction}

Firms spend considerable resources on advertising expenditures every year. As an industry, advertising represents about $2.2 \%$ of GDP in the U.S. economy (Molinari and Turino, 2009). ${ }^{1}$ Naturally, this large amount spent by corporations reflects the benefits which firms expect to generate as a result of advertising. We interpret advertising expenditures as firms' investment in brand capital, a form of intangible capital. Brand capital is a productive input because it may help firms increase their sales through, for example, increased costumer loyalty, persuasion, or other mechanism (see Bagwell, 2007). As a result, the firm's stock of brand capital contributes to the firm's total market valuation. In addition, through its effect on cash-flows, brand capital affects the overall risk of a firm, and hence its cost of capital. In this paper, we study the link between advertising expenditures, brand capital and asset returns in the cross-section of U.S. publicly traded firms both empirically and through the lens of a theoretical model of advertising expenditures.

We propose a parsimonious dynamic investment-based model to link brand capital to firm value, in a setup in which both variables are endogenously determined in equilibrium. In the model, firms make physical capital investment and advertising decisions to maximize the value of the firm for shareholders. Advertising expenditures create brand capital which has a positive, yet with diminishing returns, effect on firms' sales, consistent with the empirical evidence discussed in Bagwell (2007). Optimal advertising and physical capital investment determines firms' dividends, corporate finance policies and firm market value. The only frictions in the model are the existence of brand and physical capital adjustment costs as well as costs of issuing new equity (external finance), which we justify below. Through calibration and simulation, we use the model to investigate if optimal investment is consistent with the empirical facts relating brand capital, firm value and asset returns that we document here.

\footnotetext{
${ }^{1}$ For example, according to Bagwell (2007), in 2003, General Motors spent $\$ 3.43$ billion to advertise its cars and trucks; Procter and Gamble devoted $\$ 3.32$ billion to the advertisement of its detergents and cosmetics; and Pfizer incurred a $\$ 2.84$ billion advertising expense for its drugs.
} 
Empirically, our two main empirical findings can be summarized as follows:

1. High rates of investment in brand capital forecast low future firms' stock returns. In particular, firms with high brand capital investment rates underperform firms with low brand capital investment rates. A long-short portfolio based on firms' investment in brand capital rate has a spread of $-7 \%$ per annum.

2. Brand capital intensive firms, measured as firms' stock of brand capital per employee, outperform less brand capital intensive firms by $4 \%$ per annum.

Thus our empirical results reveal strong correlations between brand capital, and firms' stock returns. Theoretically, we show that the dynamic investment-based model studied here can replicate reasonably well both the asset pricing facts as well as the time-series properties of brand capital (advertising) and physical capital investment rates. Taken together, the consistency between the real data and the predictions from the investment-based model with rational expectations and profit maximizing firms, suggests that the stock market successfully incorporates the information about firms' investment in brand capital, a form of intangible (and hence difficult to measure) capital.

In the dynamic investment-based model, the negative relationship between the firm's future stock returns and the firm's investment rate in brand capital arises endogenously due to differences in firms' productivity, and is amplified by frictions in the adjustment of both physical and brand capital. Investment in brand capital is irreversible because it cannot be disembodied from the firm. Investment in physical capital is not irreversible, but it is particularly costly to downsize, especially in bad times when the price of risk is high. The firm's decision on how much to invest is driven by productivity: more productive firms investment more in both physical and brand capital than low productivity firms. As a result, the returns of firms with relatively lower investment rates fluctuate more closely with aggregate shocks, because it is more difficult for low productivity firms to smooth their dividends. This mechanism implies that, in the cross-section, firms that are investing 
relatively less in brand capital have endogenously higher average stock returns in equilibrium as a compensation for their higher level of risk. Analogously, brand capital intensive firms are low productivity firms which have accumulated too much brand capital, thus explaining their higher level of risk. The economic mechanism underlying this relationship is exactly analogous to the theoretical explanations of the value premium that emphasize the importance of frictions in the adjustment of capital inputs (e.g. Zhang, 2005). Our contribution to this literature is to show, both empirically and theoretically, that this exact mechanism extends to a multi-factor inputs setting (brand capital), even when the two capital inputs have distinct (yet related) properties.

In addition to the correlation between stock returns and brand capital, Lou (2010) documents that firms' advertising expenditures tend to be unusually large during years in which the firm issue new equity (seasoned equity offerings, SEOs). The firms' optimal response to productivity shocks in the investment-based model provides a natural explanation for this pattern in the data. In particular, external finance is procyclical: new equity is typically used by firms that experience large increases in productivity. When facing a large increase in productivity, firms raise investment in brand capital and issue new equity to finance the investment. Thus the model implies that brand capital investment and SEOs are positively correlated, consistent with the empirical evidence.

Related Literature: Our work is related to several strands of literature. A growing literature in empirical behavioral finance interprets the stock market response to firms' advertising expenditures as evidence of behavioral biases by investors. ${ }^{2}$ For example, Lou (2010) interprets the links between advertising expenditures, stock returns and SEOs as consistent with the hypothesis that firm managers use advertising expenditures to attract investor's attention and thus manipulate stock market prices to their (or existing shareholders) benefit.

\footnotetext{
${ }^{2}$ In related work, Grullon, Kanatas, and Weston (2004), show that advertising spending is positively associated with various liquidity measures, consistent with the predictions of Merton (1987). We don't study liquidity on our theoretical model.
} 
Chan, Lakonishok and Sougiannis (2001) interprets the spread and persistence in the returns of portfolios sorted on scaled measures of advertising expenditures as evidence suggesting that the market is too slow in incorporating the information about firms' investment in intangible capital into firms' valuation. Our empirical findings largely confirm the empirical results obtained in this literature, but provides an alternative explanation for the evidence. We show that the correlations in advertising expenditures, SEOs and stock returns observed in the data arises naturally in a setup in which firms maximize firm value and investors have rational expectations. Naturally, our explanation does not rule out these alternative behavioral explanations, since the two explanations are not mutually exclusive.

Our empirical findings are also related to the empirical asset pricing literature exploring the effect of firm characteristics on the cross-section of stock returns. We show that brand capital is a firm characteristic that is related to firms' risk in the cross-section. Fama and French (2008) provide a recent survey of the literature. Snirivasan and Hanssens (2008) survey the empirical evidence on the link between marketing (including advertising expenditures) and firm value. Without an explicit structural model however, the observed correlations in the data are difficult, if not impossible, to interpret. The structural model proposed here thus helps us understanding the observed empirical patterns.

Our focus on brand capital is also related to the asset pricing literature on intangible capital and firm risk. The closest paper to ours is Papanikolaou and Eisfeldt (2010) who show that firms with more organizational capital are riskier than firms with less organizational capital. Hansen, Heaton and Li (2004) study the risk characteristics of intangible capital. Hsu (2009) shows that technological innovations forecast stock excess returns at the aggregate level using R\&D data. Chen, Lakonishok, and Sougiannis (2001) documents a positive relation between R\&D intensity and firms' future stock returns, and Li (2007) shows that this positive relation is only present in R\&D intensive firms. Lin (2010) explains the link between R\&D expenditures and asset prices in a theoretical model. Li and Liu (2010) study the importance of intangible capital in a Q-theory model and using structural estimation. 
The model proposed here extends the standard investment-based model first used by Cochrane (1991) to link investment to firm value and stock returns. The model builds on standard Q-theory of investment and has been successful at explaining the correlations between physical investment and stock returns observed in the data (e.g. Zhang, 2005, Liu, Whited and Zhang, 2009). This empirical success makes it a natural starting point for us to examine the link between brand capital and firm value. Consistent with the main insights from standard Q-theory of investment, interpreting advertising expenditures by firms as an investment in an intangible asset represents a good starting point for understanding the link between advertising expenditures, brand capital and firm value.

Finally, our work contributes to the industrial organization as well as to the marketing literature. Schmalensee (1972) and more recently Bagwell (2007) provide a survey of the economic analysis of advertising. This literature however, largely ignores the effect of advertising on firm value and firm risk within a structural model. Our work attempts to fill this gap.

The paper proceeds as follows. Section 2 presents the dynamic investment-based model with physical capital and brand capital. Section 3 discusses the properties of the physical and brand capital investment rate in the real data and compares these properties with those

obtained from simulated data from the model. Section 4 reports the empirical cross-sectional asset pricing facts relating brand capital and stock returns in the data, and examines if the model can replicate the empirical patterns. Finally, Section 5 concludes.

\section{A Model of Advertising, Brand Capital and Firm Value}

We propose a parsimonious dynamic investment-based model to study the link between brand capital, firm value and asset returns. The framework of the model is based on the 
standard Q-theory model of investment, which has been successfully used to explain the empirical links between physical capital and firm value (e.g. Cochrane, 1991, and Zhang ,2005). Firms accumulate brand capital through advertising expenditures, and make optimal production decisions to maximize firm value. Optimal investment establishes an endogenous link between the firm's physical capital, brand capital and firms' market value and risk. Firms are all equity financed. Issuing equity is costly and is the only source of external finance. Introducing external financing costs in the model allows us to examine the link between firms' corporate finance decisions and investment in brand capital, and thus interpret the extant empirical evidence on this relationship (Lou, 2010).

\subsection{Economic Environment}

The economy is composed of a large number of firms and each firm produces a differentiated good. Firms have some degree of market power thus facing a downward slopping demand curve for their output. In addition, firms use advertising expenditures to create brand capital which in turn increases the demand for their goods. Firms take as given the marketdetermined stochastic discount factor $M_{t, t+1}$, used to value the cash-flows arriving in period $t+1$, as well as the stochastic wage rate $W_{t+1}$. The existence of a strictly positive stochastic discount factor is guaranteed by a well-known existence theorem if there are no arbitrage opportunities in the market (see for example, Cochrane, 2002, chapter 4.2).

\subsubsection{Technology}

We focus on the optimal production decision problem of one firm in the economy (we suppress any firm specific subscript to save on notation). The firm uses capital inputs $K_{t}$, and labor inputs, $L_{t}$, to produce output, $Y_{t}$, according to the constant returns to scale technology:

$$
Y_{t}=e^{x_{t}+z_{t}} K_{t}^{\alpha} L_{t}^{1-\alpha}
$$


where $\alpha>0, x_{t}$ is an aggregate productivity shock, and $z_{t}$ is the firm's specific idiosyncratic productivity shock. The aggregate productivity shock follows the process

$$
x_{t+1}=\bar{x}\left(1-\rho_{x}\right)+\rho_{x} x_{t}+\sigma_{x} \varepsilon_{t+1}^{x},
$$

where $\varepsilon_{t+1}^{x}$ is an independently and identically distributed (i.i.d.) standard normal shock. The idiosyncratic productivity shock follows the process

$$
z_{t+1}=\rho_{z} z_{t}+\sigma_{z} \varepsilon_{t+1}^{z}
$$

where $\varepsilon_{t+1}^{z}$ is an i.i.d standard normal shock that is uncorrelated across all firms in the economy, and $\varepsilon_{t+1}^{x}$ is independent of $\varepsilon_{t+1}^{z}$ for each firm. In the model, the aggregate productivity shock is the driving force of economic fluctuations and systematic risk, and the idiosyncratic productivity shock is the driving force of firm heterogeneity.

In every period $t$, the capital stock $K_{t}$ depreciates at rate $\delta_{k}$ and is increased (or decreased) by gross investment $I_{t}$. The law of motion of the capital stock is given by

$$
K_{t+1}=\left(1-\delta_{k}\right) K_{t}+I_{t}, \quad 0<\delta_{k}<1
$$

When changing the capital stock, firms' incur in capital adjustment costs. As standard from the q-theory of investment literature, capital adjustment costs include planning and installation costs, learning the use of new equipment, or the fact that production is temporarily interrupted. These costs are specified by the following convex asymmetric quadratic adjustment cost function

$$
C^{I}\left(I_{t}, K_{t}\right) \equiv \frac{\theta_{t}}{2}\left(\frac{I_{t}}{K_{t}}\right)^{2} K_{t},
$$


where

$$
\theta_{t} \equiv \theta^{+} . \varkappa\left\{i_{t} \geq 0\right\}+\theta^{-} . \varkappa\left\{i_{t}<0\right\}
$$

Here, $\varkappa\left\{i_{t} \geq 0\right\}$ is an indicator function that equals one if the event described in $\{$.$\} is true$ and zero otherwise. The adjustment cost function is asymmetric, that is $\theta^{-}>\theta^{+}>0$, to capture the intuition of costly reversibility in Zhang (2005).

In addition to physical capital, firms accumulate brand capital through advertising expenditures $\left(A_{t}\right)$. The law of motion of brand capital is given by the standard law of motion:

$$
B_{t+1}=\left(1-\delta_{B}\right) B_{t}+A_{t}
$$

in which $\delta_{B}$ is the depreciation rate of brand capital.

Investment in brand capital is irreversible, that is $A_{t} \geq 0$ which means that brand capital cannot be disembodied from the firm. Similar to physical capital, firms' incur in adjustment costs when expanding the stock of brand capital. These costs capture the notion that planning of advertising campaigns is costly. In addition, advertising expenditures may be associated with an increase in costumer support, discounts, etc. Finally, low scale local advertising campaigns are less expensive than large scale national campaigns since the later require the use of professional advertising agencies whereas the former can be done in-house. These costs are specified by the following convex adjustment cost function:

$$
C^{A}\left(A_{t}, B_{t}\right) \equiv \frac{c_{b}}{2}\left(\frac{A_{t}}{B_{t}}\right)^{2} B_{t},
$$

where $c_{b}>0$ is a constant.

\subsubsection{Goods Market}

Each firm faces a downward sloping demand curve given by: 


$$
P\left(B_{t}, Y_{t}\right)=B_{t}^{\gamma} Y_{t}^{-\frac{1}{\varepsilon}}, \text { where } 0 \leqslant \gamma<1 \text { and } \varepsilon>1
$$

in which $\varepsilon$ is the demand elasticity of the good. In this specification, the stock of brand capital increases the consumers' willingness to pay for the firms good $\left(Y_{t}\right)$. Thus all else equal, a higher stock of brand capital allows firms to increase sales, but at a diminishing rate $(\gamma<1)$. The positive effect of brand capital on firms' sales is consistent with the empirical evidence surveyed in Bagwell (2007, section 3.1.1) and Schmalensee (1972, ch. 4). ${ }^{3}$

\subsubsection{Labor Market}

The supply of labor is perfectly elastic at the (stochastic) wage rate $W_{t}$ (or labor cost per worker), which firms take as given. Following Bazdresch, Belo and Lin (2009), the equilibrium wage rate $W_{t}$ is assumed to be an increasing function of the demeaned aggregate productivity shock:

$$
W_{t}=\lambda \exp \left(w\left(x_{t}-\bar{x}\right)\right)
$$

with $\lambda>0$ and $0<w<1$. In this specification, $\lambda$ is a scaling factor and the constraint $0<w<1$ allows us to capture the fact that the aggregate real wage rate is less volatile than aggregate productivity (output) as well as some, albeit very small, procyclicality of the real wage rate, as reported in Gomme and Greenwood (1995), Merz and Yashiv (2007) and Gourio (2007) in US data. ${ }^{4}$

\footnotetext{
${ }^{3}$ Some of the empirical work establishing a link between advertising expenditures and sales include Lambin (1976), who find that brand advertising has a significant and positive effect on the brand's current sales and market share. A non-comprehensive list of other studies include, Palda (1964), Peles (1971), Telser (1962), Nelson (1974), among others.

${ }^{4}$ As reported in Gomme and Greenwood (1995) the international evidence on the procyclicality of the real wage rate is mixed, but is slightly procyclical in the US economy.
} 


\subsubsection{Stochastic Discount Factor}

Following Zhang (2005), we directly specify the stochastic discount factor (henceforth SDF) without explicitly modeling the consumer's problem. The stochastic discount factor is given by

$$
\begin{aligned}
\log M_{t, t+1} & =\log \beta+\gamma_{t}\left(x_{t}-x_{t+1}\right) \\
\gamma_{t} & =\gamma_{0}+\gamma_{1}\left(x_{t}-\bar{x}\right)
\end{aligned}
$$

where $M_{t, t+1}$ denotes the stochastic discount factor from time $t$ to $t+1$. The parameters $\left\{\beta, \gamma_{0}, \gamma_{1}\right\}$ are constants satisfying $1>\beta>0, \gamma_{0}>0$ and $\gamma_{1}<0$. In equation (11), $\gamma_{t}$ is time-varying and decreases in the demeaned aggregate profitability shock $x_{t}-\bar{x}$, to capture the well documented countercyclical price of risk with $\gamma_{1}<0$. The stochastic discount factor is in units of a numeraire consumption good with price normalized to 1 . The existence of a numeraire good can be motivated by the existence of a representative household which converts each differentiated good one-for-one into an the homogeneous numeraire good, as in Gourio and Rudanko (2010).

\subsubsection{Corporate Policies}

Define firms' operating profit as:

$$
\Pi_{t}=P\left(B_{t}, Y_{t}\right) \cdot Y_{t}-P_{a} \cdot A_{t}-f
$$

where $P_{a}$ is the per unit price of advertising and $f$ is a fixed cost. The production of advertisements is generally a very competitive industry, where advertisers hire agencies to prepare copy for them (Becker and Murphy, 1993) Competition implies that the marginal cost to advertisers of a unit of advertising would equal the marginal cost of preparing it. We assume $P_{a}$ is thus equal to the marginal cost of producing an unit of advertising, and this 
cost is constant over time. We set $P_{a}=1$.

All firms in the economy are assumed to be all-equity financed. When the sum of investment, $I_{t}$ and total adjustment costs, $C_{t} \equiv C^{I}\left(I_{t}, K_{t}\right)+C^{A}\left(A_{t}, B_{t-1}\right)$, exceeds internal funds, $\Pi_{t}$, the firm raises new equity capital, $e_{t}$, from external markets:

$$
e_{t} \equiv \max \left(0, I_{t}+C_{t}-\Pi_{t}\right)
$$

As in Li, Livdan, and Zhang (2009), we assume that new equity is the only source of external finance. External equity is costly (e.g., Smith 1977; Lee 1996; Altinkilic and Hansen 2000). To capture this effect, we follow Gomes (2001), Hennessy and Whited (2005) and Li, Livdan and Zhang (2009), and assume that for each dollar of external equity raised, firms must pay proportional flotation costs. There also are fixed costs of financing. Thus, we parameterize the total financing-cost function as

$$
\Lambda_{t} \equiv \Lambda\left(e_{t}\right)=\lambda_{0} \mathbf{1}_{\left\{e_{t}>0\right\}}+\lambda_{1} e_{t}
$$

in which $\lambda_{0}>0$ captures the fixed costs, $\left.\mathbf{1}_{\left\{e_{t}>0\right\}}\right\}$ is the indicator function that takes the value of one if the event described in $\{\cdot\}$ occurs, and $\lambda_{1} e_{t}>0$ captures the proportional costs.

When the sum of investment and adjustment costs is lower than internal funds, the firm pays the difference back to shareholders. The payout, $\mathrm{D}_{t}$ is defined as

$$
D_{t}=\max \left\{0, \Pi_{t}-I_{t}-C_{t}\right\}
$$

\subsection{Firm Value, Risk and Return}

Define $\mathrm{O}_{t}$

$$
O_{t} \equiv D_{t}-e_{t}-\Lambda\left(e_{t}\right)=\Pi_{t}-I_{t}-C_{t}-\Lambda\left(e_{t}\right)
$$


to be the effective cash flow accrued to shareholders (cash distributions minus the sum of external equity raised and the financing costs).

Define the vector of state variables as $s_{t}=\left(x_{t}, z_{t}, K_{t}, B_{t-1}\right)$ and let $\mathrm{V}^{\text {cum }}\left(s_{t}\right)$ be the cumdividend market value of the firm in period $t$. The firm makes advertising $A_{t}$ and physical investment $I_{t}$ decisions to maximize its cum-dividend market value by solving the problem:

$$
V^{\mathrm{cum}}\left(s_{t}\right)=\max _{A_{t+j}, I_{t+j}, j=0 . . \infty}\left\{\mathbb{E}_{t}\left[\sum_{j=0}^{\infty} M_{t, t+j} O_{t+j}\right]\right\},
$$

subject to equations (4), (7), and (13). The operator $\mathbb{E}_{t}[$.$] represents the expectation over$ all states of nature given all the information available at time $t$.

In the model, risk and expected stock returns are determined endogenously along with the firm's optimal production decisions. To make the link explicit, we can evaluate the value function in equation (14) at the optimum,

$$
\begin{aligned}
V^{\mathrm{cum}}\left(s_{t}\right) & =O_{t}+\mathbb{E}_{t}\left[M_{t, t+1} V^{\mathrm{cum}}\left(s_{t+1}\right)\right] \\
& \Rightarrow 1=\mathbb{E}_{t}\left[M_{t, t+1} R_{t+1}^{s}\right]
\end{aligned}
$$

where equation (15) is the Bellman equation for the value function and equation (16) follows from the standard formula for stock return $R_{t+1}^{s}=V^{\text {cum }}\left(s_{t+1}\right) /\left[V^{\text {cum }}\left(s_{t}\right)-O_{t}\right]$. Note that if we define $P_{t}^{s} \equiv V^{\text {cum }}\left(s_{t}\right)-O_{t}$ as the ex-dividend market value of equity, $R_{t+1}^{s}$ reduces to the usual definition, $R_{t+1}^{s} \equiv\left(P_{t+1}^{s}+O_{t+1}\right) / P_{t}^{s}$. Equation (16) can then be written in the standard expected return-beta form. Following Cochrane (2001 p. 19):

$$
\mathbb{E}_{t}\left[R_{t+1}^{s}\right]=R_{f t}+\beta_{t} \lambda_{m t}
$$


where $R_{f t} \equiv \frac{1}{\mathbb{E}_{t}\left[M_{t, t+1}\right]}$ is the real (gross) interest rate, and $\beta_{t}$ is the firm's risk defined as:

$$
\beta_{t} \equiv \frac{-\operatorname{Cov}_{t}\left[R_{t+1}^{s}, M_{t, t+1}\right]}{\operatorname{Var}_{t}\left[M_{t, t+1}\right]}
$$

and $\lambda_{m t}$ is the price of risk defined as

$$
\lambda_{m t} \equiv \frac{\operatorname{Var}_{t}\left[M_{t, t+1}\right]}{E_{t}\left[M_{t, t+1}\right]} .
$$

\section{Brand Capital and Real Quantities}

All the endogenous variables in the model, including risk and expected return, are functions of the state variables. Because the functional forms are not available analytically, we solve for these functions numerically.

Here, we first characterize the real data and report the summary statistics of the key variables in our study: brand capital and physical capital investment rates. We then calibrate the model by matching key cross-sectional and asset pricing moments. To produce the model implied moments, we simulate 100 artificial panels, each of which has 3600 firms and 800 months and report the cross-panel average moments. In each simulation of the model, we start by assuming the initial capital stocks of all firms to be at their long-run average level and by drawing their firm-specific productivity levels from the unconditional distribution of $z_{t}$. We drop the initial 200 months of data to neutralize the effect of the initial conditions. The remaining 600 months of data are treated as those from the stationary distribution. Appendix A provides a description of the solution algorithm and of the numerical implementation of each model. 


\subsection{Data}

Monthly stock returns are from the Center for Research in Security Prices (CRSP) and accounting information is from the CRSP/COMPUSTAT Merged Annual Industrial Files. The sample is from July 1975 to December 2009 (before 1975 most firms do not report advertising expenditure data). We exclude from the sample any firm-year observation with missing data or for which total assets or the gross capital stock are either zero or negative. In addition, as standard, we omit firms whose primary SIC classification is between 4900 and 4999 (regulated firms) or between 6000 and 6999 (financial firms). Following Fama and French (1993), we also require that each firm must have at least two years of data to be included in the sample (avoid backfill bias).

The main variables in our study are constructed as follows. Firm level capital investment $\left(\mathrm{I}_{t}\right)$ is given by COMPUSTAT data item capex (capital expenditures) minus data item sppe (sales of property plant and equipment). The capital stock $\left(\mathrm{K}_{t}\right)$ is given by the data item nppe (net property, plant and equipment). The physical capital investment rate is then given by the ratio of physical investment to the beginning of the period capital stock $\left(\mathrm{IK}_{t}=\mathrm{I}_{t} / \mathrm{K}_{t-1}\right)$.

Advertising expenditures $\left(\mathrm{A}_{t}\right)$ is given by COMPUSTAT data item xad (advertising expense). The stock of brand capital $\left(B K_{t}\right)$ is an intangible asset, and thus it is naturally difficult to measure. We follow the literature on intangible capital and construct the stock of brand capital from past advertising expenditures data and using the perpetual inventory method: ${ }^{5}$

$$
B K_{t}=(1-\delta) B K_{t-1}+A_{t}
$$

To implement the law of motion in Equation (19) we must choose an initial stock and a depreciation rate. We follow the perpetual inventory method, and choose the initial stock

\footnotetext{
${ }^{5}$ See also Lev et al (1999), Dube, Hitsch and Manchanda (2005), Papanikolaou and Eisfeldt (2010), and Li and Liu (2010) for similar applications. The Bureau of Economic Analysis uses a similar methodology to construct a stock of Research and Development capital, see Sliker (2007).
} 
according to:

$$
B K_{0}=\frac{A_{0}}{g+\delta} .
$$

where $A_{0}$ is the firms' advertising expenditure in the first year in the sample. We use a depreciation rate of $50 \%$. This seemingly large value for the brand capital depreciation rate is consistent with the empirical evidence surveyed in Bagwell (2007). For example, Lambin (1976, p.96) reports that the depreciation-rate estimates are on average around $50 \%$ per year across a series of product (our key asset pricing results are robust to using other depreciation rates, e.g. $\delta=20 \%$ ). We choose $g$ to match the average growth rate of advertising expenditures, which in our sample equals $10 \%$. The brand capital investment rate is then given by the ratio of advertising expenditures to the beginning of the period brand capital stock $\left(I B K_{t}=A_{t} / B K_{\mathrm{t}-1}\right)$. Firms with missing advertising expenditures are dropped from the sample. This leaves us with 30646 firm-year observations. Appendix B provides a detailed description of the additional data used as well as additional sample selection criteria.

\subsection{Business Cycle Properties}

Table 1, Panel A reports summary statistics of the firm level physical capital investment rate (IK), investment in brand capital rate (IBK) as well as labor growth ( $\Delta$ Labor) and the real net sales growth $(\Delta$ Sales $)$ in the data.

\section{[Insert Table 1 here]}

In the data, the properties in investment in brand capital and physical capital are comparable. Both investment rates are very volatile at the firm level (25\% and 32\% per annum for physical investment and brand capital investment, respectively) and have roughly the same autocorrelation $(\mathrm{AC}(1)=21 \%$ and $18 \%)$. The mean correlation between the firm's

physical capital investment rate and brand capital investment rate is positive (19\%), and both variables are strongly procyclical: the correlation of physical capital investment rate and 
brand capital investment rate with real sales growth is positive $(30 \%$ and $29 \%$ per annum, respectively). The analysis of the firm level moments reported here is consistent with the analysis in Molinari and Turino (2009) for the aggregate level properties of investment in brand capital and physical capital in the U.S. economy (see their Tables 1 and 2).

\subsection{Calibration}

The model is calibrated at monthly frequency using the parameter values reported in Table 2. The first set of parameters specifies the technology of the firm. The second set of parameters describes the exogenous stochastic processes that the firm faces, including the aggregate and idiosyncratic profitability shock, and the stochastic discount factor. Because the accounting variables in the real data are observed at annual frequency, the simulated monthly data is aggregated to annual frequency.

[Insert Table 2 here]

The choice of the parameter values is based on the parameter values reported in previous studies whenever possible, or by matching known aggregate asset pricing facts, as well as key firm level real quantity moments reported in Table 1.

Firm's technology: We set the elasticity of output with respect to capital in the production function (1) to be $\alpha=0.36$, similar to Cooley and Prescott (1995) and Gomes (2001). The

elasticity of price with respect to brand capital $\gamma$ is set to match the average brand capital to physical capital ratio which is 0.3 in our sample. We follow Caballero and Pindyck (1996) and Zhang (2005) and set the price elasticity of demand $\varepsilon$ to be 2 . The monthly capital depreciation rate $\delta_{k}$ is set as $1 \%$ per month as in Zhang (2005). The monthly depreciation rate of brand capital is set at $\delta_{n}=4.16 \%$ per month, which corresponds to an annual 
depreciation rate of $50 \%$, consistent the empirical procedure used to estimate brand capital in the data.

Empirical estimates of the slope adjustment cost parameters vary substantially across studies and so they are difficult to calibrate. Our calibration strategy is to match firm-level real quantities as close as possible. We set the upward and downward parameters in the convex capital adjustment cost functions at $\theta^{+}=1$ and $\theta^{-}=10$ to match the persistence and volatility of the capital investment rate. Similarly, the slope adjustment cost of brand capital is set $c_{b}=0.25$ to match the persistence and volatility of brand capital investment rate. ${ }^{6}$ We set the two parameters in the wage rate function at $\lambda=0.02$, and $\omega=0.1$ such that the average wage payment to output is $60 \%$. Finally, we set the fixed cost $f$ to roughly match the average firm level book equity to market equity ratio of 1.4 . We calibrate the fixed financing and proportional financing costs parameters to match the average equity issuance of $25 \%$, reported in Li, Lidvan and Zhang (2009)

Stochastic processes: We set the persistence of the aggregate productivity shock at $\rho_{x}=0.95^{1 / 3}$ and its conditional volatility at $\sigma_{x}=0.007 / 3$, which roughly corresponds to the quarterly estimates in Cooley and Prescott (1995). The long-run average level of aggregate productivity shock, $\bar{x}$, is a scaling variable. Following Zhang (2005), we set the average long-run capital in the economy at one. To calibrate the persistence parameter $\rho_{z}$ and the conditional volatility parameter $\sigma_{z}$ of the firm-specific profitability shock, we follow Zhang (2005) and restrict these two parameters using their implications on the degree of dispersion in the cross-sectional distribution of firms' stock return volatilities. Thus we set $\rho_{z}=0.97$, and $\sigma_{z}=0.10$, which implies an average annual volatility of individual stock returns of 25\%, approximately the average reported by Campbell et al (2001).

Following Zhang (2005), we pin down the three parameters governing the stochastic discount factor, $\beta, \gamma_{0}$, and $\gamma_{1}$ in equation (10) and (11), by matching three aggregate return

\footnotetext{
${ }^{6}$ Note that due to irreversibility constraint, the downward adjustment costs of brand capital investment is effectively infinite, which plays a relevant role in determining volatility and persistence.
} 
moments: the average real interest rate, the volatility of the real interest rate, and the average maximum levered Sharpe ratio in the U.S economy (approximately 0.4). This procedure yields $\beta=0.95, \gamma_{0}=50$, and $\gamma_{1}=-1000$.

The model does a reasonable job matching key firm level real quantity moments. Table 1, Panel B shows that the model is roughly consistent with the properties of investment in brand capital and physical capital in the data reported in Panel A. The mean of both series is pinned down by the depreciation rate. In the model, the means are smaller than in the data because the model has no growth. The volatility and the autocorrelation of the two investment series is comparable with the data. The model implied correlation between investment in brand capital and physical capital is too high in the model relative to the data. This is expected given that essentially the model is a one aggregate shock model. In addition, in contrast with the data, the model variables are observed without any measurement error. Finally, consistent with the data, both series are strongly procyclical: the correlation with sales growth is 0.55 for investment in physical capital and 0.70 for investment in brand capital.

\section{Brand Capital and Asset Returns}

In this section, we examine the link between advertising expenditures, brand capital and asset returns in the cross-section of U.S. publicly traded firms. To facilitate the analysis and the interpretation of the results, we report simultaneously the link in the real data together with the equivalent moments generated by the model. The empirical analysis of the cross sectional asset pricing facts reported here extends the analysis in Lou (2010) and Chan, Lakonishock and Sougiannis (2001), who also examine the link between advertising expenditures and stock returns in the cross-section. 


\subsection{Investment in Brand Capital Portfolios}

To examine the link between brand capital, firm value and asset returns, we construct five portfolios sorted on firm level brand capital investment rate. We then investigate the properties of post formation average excess stock returns and other characteristics of the portfolios.

Following Fama and French (1993), in each June of year $t$, we sort the universe of common stocks into five equally-sized portfolios based on the firm's brand capital investment rate at the end of year $t-1$. Once the portfolios are formed, their equally-weighted returns are tracked from July of year $t$ to June of year $t+1$. The procedure is repeated in June of year $t+1$. We focus on equally-weighted returns because it produces a considerably larger spread in returns across the brand capital portfolios, thus making it harder for the theoretical asset pricing model that we consider here to match the data (Liu, Whited and Zhang, 2009). In addition, this choice allows us to examine the relationship between risk and returns across the overall economy, not only among the very large firms that dominate the value-weighted portfolios. However, equally-weighted portfolios tend to be dominated by very small firms that are typically iliquid assets and thus difficult to trade in the stock market. To address

this concern we have re-computed all our portfolios and tests excluding micro cap firms (defined as firms with market capitalization in the bottom $10 \%$ percentile of the NYSE market capitalization cross-sectional distribution), and obtained very similar results to those reported here.

[Insert Table 3 here]

Table 3, Panel A reports the time-series average of portfolio excess stock returns, and the corresponding t-statistics in parenthesis. In the real data, the average excess returns of the investment in brand capital portfolios are decreasing in the brand capital investment rate, consistent with the results in Lou (2010) for advertising growth portfolios. This result is analogous to the well established negative correlation between physical capital investment 
rates and future stock returns documented in the previous literature (Cochrane, 1991). The spread in the average excess returns of these portfolios is large: the difference between the returns of the high and low investment in brand capital portfolio is $-6.9 \%$ per annum, which is more than 3.9 standard errors from zero.

The time-series average of the portfolio excess stock returns generated by the model are largely consistent with those in the data. The simulated portfolio average excess returns are decreasing in the brand capital investment rate, and the difference between the returns of the high and low investment in brand capital portfolio is $-5.65 \%$ per annum. The fact that the model can replicate the pattern in returns of these portfolios, suggests that the observed pattern in the data is consistent with firm value maximization, and rational expectations. It also suggests that the market incorporates the information about firms' investment in intangible capital. Thus our model provides a quantitatively reasonable alternative explanation to the Chan, Lakonishok and Sougiannis (2001)'s and Dou (2010)'s behavioral bias interpretation of the link between investment in intangible capital and future stock returns discussed in the introduction.

Table 3, Panel B reports the average excess returns of the investment in brand capital portfolios across different horizons before and after portfolio formation. Interestingly, in the real data, firms in the low investment in brand capital portfolio have considerably lower past average excess returns in the previous three years before portfolio formation than firms in the high investment in brand capital portfolio: $10.80 \%$ versus $19.21 \%$ per annum, a spread of $+8.41 \%$. In the first year after portfolio formation, the performance is reversed as reported above. In the second and third year after portfolio formation, the difference in returns of the low and high investment in brand capital portfolio decreases but at a slow rate: the spread in the first year is $-6.90 \%$, in the second year is $-3.97 \%$ per annum, and in the third year after portfolio formation the spread is $-3.63 \%$. The data generated by the model is largely consistent with the pattern observed in the real data, although the model slightly overstates the spread in average returns in the three years prior to portfolio formation. 
Table 3, Panel C reports the time-series average of accounting variables measured at the time of portfolio formation (we use within portfolio cross-sectional median as the measure of portfolio level characteristics). Firms in the low brand capital investment rate portfolio relative to firms in the high brand capital investment rate portfolio have lower physical capital investment rates, lower past sales growth ( $-1 \%$ vs 15\%), have higher book-to-market ratios (0.82 vs 0.62$)$ and are slightly smaller. Here too, the data generated by the model is largely consistent with the pattern of portfolio characteristics observed in the real data. The negative correlation between invest in brand capital and the book-to-market ratio is not surprising and consistent with the model. From standard Q-theory, the shadow price of brand capital is increasing in firms' investment rate. Thus firms that invest relatively more in brand capital, have higher market value and thus lower book-to-market ratios.

Finally, Table 4 reports the transition matrix of securities across portfolios. Again, the properties of the transition probabilities in the model and in the data are comparable. In particular, due to the reasonably close persistence of the brand capital investment rate in the real and simulated data, the diagonal entries are larger than the off-diagonal entries. Thus securities in a given portfolio have a larger probability of staying in the same portfolio in the subsequent year, both in the real data and in the model.

[Insert Table 4 here]

\subsection{Other Brand Capital Portfolios}

To provide a comprehensive characterization of the link between brand capital and stock returns in the data, we extend the previous analysis and examine two other alternative brand capital portfolios. Here, we construct five portfolios sorted on advertising growth rate (following Lou, 2010) and five portfolio sorted on brand capital to labor ratio. The sorting on advertising growth is an alternative way of sorting on investment in brand capital and allows us to construct portfolios that do not depend on our specific construction of brand 
capital stock. In turn, these portfolios allows us to examine the robustness of our previous findings. The sorting on brand capital to labor ratio allows us to investigate the variation in risk associated with firms with different brand capital intensities (see Papanikolaou and Eisfeldt (2010) for similar procedure in the context of organizational capital). If the cashflows generated from brand capital and labor have different properties, it is natural to expect that the total firm risk varies across firms with different brand capital intensities.

\section{[Insert Table 5 here]}

Table 5, top panel, reports the return properties of five portfolios sorted on advertising growth. The average excess returns of the advertising growth portfolios are are decreasing in the brand capital investment rate, confirming the results in Lou (2010) and consistent with the results for the investment in brand capital portfolios. The spread in the return of the high advertising growth and the low advertising growth portfolios is $-6.35 \%$ per annum, which is quite close to the spread in the returns across the investment in brand capital portfolios $(-6.90 \%)$. The model successfully replicates the large spread in the returns of these portfolios $(-5.60 \%$ per annum). This result confirms that the previous results on investment in brand capital portfolios is not driven by the particular construction of the stock of brand capital.

Table 5, bottom panel, reports the return properties of five portfolios sorted on brand capital to labor ratio. Interestingly, firms that are more brand capital intensive have on average higher excess returns than firms that are low brand capital intensive. The difference in average returns of the high and low portfolios is $4.04 \%$, which is more than 2.5 standard errors from zero. The model is qualitatively consistent with this spread, but it slightly overstates its magnitude: $8.71 \%$ per annum. Since both organizational capital and brand capital are intangible assets, this result is consistent with the findings in Papanikolaou and Eisfeldt (2010) who first show that organizational capital intensive firms have higher average returns than less organizational capital intensive firms. However, the explanation proposed by our model is quite different. In Papanikolaou and Eisfeldt (2010) organizational capital is 
risky because it is partially embodied in firms' labor input and thus cannot be wholly owned by shareholders. This makes organizational capital risky because the division of firms' rents between labor and shareholders varies over time, exposing shareholders to an additional risk factor. Our story is based on the standard Q-theory of investment and emphasizes the importance of frictions in the adjustment of capital stocks. Accordingly, brand capital is riskier than labor because it is relatively more costly to adjust brand capital. ${ }^{7}$

Taken together, the results in this section document strong correlations between firms' investment in brand capital, brand capital intensity and future stock returns. Given that these patterns are replicated in the artificial data generated by the dynamic investmentbased model, this result suggest that optimal investment is a plausible important driver of this pattern. It also suggests that the stock market successfully incorporates the information about firms' investment in brand capital, a form of intangible capital. Finally, our analysis suggests that brand capital is a risky asset, since firms' more brand capital intensive (per unit of worker) have on average higher returns than firms low brand capital intensive firms.

\subsection{Investment in Brand Capital and SEOs}

The empirical finance literature studies the pattern of advertising expenditures around seasoned equity offerings (SEOs). For example, Lou (2010) documents that firms' advertising expenditures are unusually large in periods in which firms issue equity. This interesting analysis is motivated as follows. If some investors suffer from limited attention and/or other forms of behavioral biases in forming expectations, increased advertising expenditures can cause higher contemporaneous stock returns but lower subsequent returns. This mechanism occurs because advertising increases the buying pressure through higher visibility of the stocks without necessarily changing the supply side pressure (because sellers hold a small

\footnotetext{
${ }^{7}$ For simplicity and to focus on the properties of brand capital, we abstract from labor adjustment costs in our model (see Bazdresch, Belo and Lin, 2010 for a study of the impact of labor adjustment costs on firms' risk). Our analysis remains valid provided that is relatively less costly to adjust labor than brand capital. Our empirical results for the brand capital to labor ratio portfolios seem to suggest that this is an empirically plausible assumption.
} 
number of stocks, they are likely to suffer less from limited attention).

Interestingly, the model can replicate the positive correlation between advertising expenditures and firms' decision to issue stock. In the model, firms who issue stocks are those firms with better investment opportunities, that is, high productivity firms. The high productivity leads to the positive correlation between advertising expenditures and stock issuance: (i) firms want to investment more in brand capital to take advantage of the high marginal product of capital; and (ii) to finance the investment, firms raise external equity by issuing stock.

To illustrate this mechanism, Figure 1 plots the impulse response of investment in brand capital (IBK), investment in physical capital (IK) and external finance (Fin), to a one percentage increase in the aggregate productivity shock. External finance is defined as negative dividends. Positive external finance is interpreted as a seasoned equity offering (SEO). As a response to the positive productivity shock, the investment in both physical and brand capital increase, as well as the amount raised in external finance. Thus the model provides an alternative interpretation for the empirical findings. The fact that external finance and investment are procyclical is well known (Li, Lidvan and Zhang, 2009).

[Insert Figure 1 here]

\section{Conclusion}

We provide a theoretical and empirical analysis of the link between advertising expenditures, brand capital, and asset returns in the cross-section of U.S. publicly traded firms. Interpreting advertising expenditures as firms' investment in brand capital, we document that: (i) firms with higher brand capital investment rates outperform firms with lower brand capital investment rates by $7 \%$ per annum; and (ii) brand capital intensive firms outperform low brand capital intensive firms by $4.1 \%$ per annum. We develop a dynamic investmentbased model that replicates the empirical asset pricing facts reasonably well. In addition, 
the model is consistent with the time-series properties of brand capital and physical capital investment rates, as well as with the unusually high advertising expenditures during seasoned equity offerings. Taken together, our results suggest that standard Q-theory of investment provides a useful framework for understanding the dynamics of advertising expenditures by corporations. 


\section{References}

Altinkilic, O., and R. S. Hansen. 2000. Are There Economies of Scale in Underwriting Fees? Evidence of Rising External Financing Costs. Review of Financial Studies 13:191-218

Bagwell,Kyle, 2007, The economic analysis of advertising, Handbook of Industrial Organization, Vol 3, 1701-1844

Bazdresch, Santiago, Frederico Belo and Xiaoji Lin, 2009, Labor hiring, investment and the stock return predictability in the cross section, Working Paper, University of Minnesota and London School of Economics and Political Science

Becker, Gary and Kevin M. Murphy, 1993, A simple theory of advertising as a good or bad, The Quarterly Journal of Economics, Vol. 108, No. 4., pp. 941-964

Caballero, Ricardo J., and Robert S. Pindyck, 1996, Uncertainty, investment, and industry evolution, International Economic Review 37, 641-662.

Campbell, John Y., Martin Lettau, Burton G. Malkiel, and Yexiao Xu, 2001, Have individual stocks become more volatile? An empirical exploration of idiosyncratic risk, Journal of Finance, 56(1), 1 - 43

Cochrane, John, 1991, Production-based asset pricing and the link between stock returns and economic fluctuations, Journal of Finance 461, 209 - 237

Cochrane, John, 2001, Asset Pricing (Princeton University Press, NJ)

Cooley, T. F., and E. C. Prescott. 1995. Economic Growth and Business Cycles. In Thomas F. Cooley (ed.), Frontiers of Business Cycle Research. Princeton, NJ: Princeton University Press

Chan, Louis, Josef Lakonishok and Theodore Sougiannis, 2001, The stock market valuation of research and development expenditures, Journal of Finance 56, 2431 - 2456

Dube, Jean-Pierre, Gunter Hitschand Punnet Manchanda, 2005, An empirical model of advertising dynamics, Quantitative Marketing and Economics 3, 107 - 144

Fama, Eugene F., and Kenneth R. French, Dissecting anomalies, Journal of Finance 63 (4), $1653-1678$

Gomme, Paul and Jeremy Greenwood, 1995, On the cyclical allocation of risk, Journal of Economic Dynamics and Control, Elsevier, 19 (1-2), 91-124

Gomes, João F, 2001, Financing investment, American Economic Review, 91(5), 1263-1285

Gourio, Francois, 2007, Labor leverage, firms heterogeneous sensitivities to the business cycle, and the cross-section of returns, Working Paper, Boston University 
Gourio, Francois and Leena Rudanko, 2010, Customer Capital, Working Paper, Boston University

Grullon, Gustavo, George Kanatas, and James P. Weston, 2004, Advertising, Breadth of Ownership, and Liquidity, Reviewof FinancialStudies 17, 439-461

Hansen, L. P., Heaton, J. C. and Li, N. ,2004, Intangible risk?, Working paper.

Hsu, Po-Hsuan, 2009, Technological innovations and aggregate risk premiums, Journal of Financial Economics, 94 (2), 264-279.

King, R., and S. Rebelo. 1999. Resuscitating real business cycles. In Handbook of Macroeconomics, 927-1007, eds. John Taylor and Michael Woodford. Oxford: NorthHolland

Lambin, J.J., 1976, Advertising, competition and market conduct in oligopoly over time, North-Holland, Amsterdam

Lee, I., S. Lochhead, J. R. Ritter, and Q. Zhao. 1996. The Costs of Raising Capital. Journal of Financial Research 19:59-74.

Li, Erica X. N., Dmitry Livdan, and Lu Zhang, 2009, Anomalies, Forthcoming, Review of Financial Studies

Li, Erica and Laura Li, 2010, Intangible assets and cross-sectional stock returns: evidence from structural estimation, Working paper, University of Michigan

Lin, Xiaoji, 2010, Endogenous technological progress and the cross section of stock returns, Journal of Financial Economics, forthcoming

Liu, L. X., Whited, T. M. and Zhang, L. (2009). Investment-based expected stock returns, Journal of Political Economy, 117(6): 1105-1139.

Lou, Dong, 2010, Maximizing short-term prices through advertising, Working Paper, London School of Economics and Political Science

McGrattan, E. 1999. Application of weighted residual methods to dynamic economic models. In Computational Methods for the Study of Dynamic Economies, Chapter 6, eds. R. Marimon and A. Scott. Oxford: Oxford University Press

Merton, Robert C., 1987, A simple model of capital market equilibrium with incomplete information, Journal of Finance 42, 483-510

Merz, Monika and Eran Yashiv., 2007, Labor and the market value of the firm, American Economic Review, 97 (4), 1419-1431

Molinari, Benedetto and Francesco Turino, 2009, Advertising and business cycle fluctuations, Working paper, University Pompeu Fabra 
Nelson, P., 1974, Advertising as information, Journal of Political Economy 82, pp. 729-754

Palda, K.S. , 1964, The measurement of cumulative advertising effects, Prentice-Hall, Englewood Cliffs, NJ

Papanikolaou, Dimitris and Andrea Eisfeldt, Organizational capital and the cross-section of expected returns, working paper, Northwestern University

Peles, Y., 1971, Rates of amortization of advertising expenditures, Journal of Political Economy 79 (1971), 1032-1058

Rouwenhorst, G. 1995. Asset pricing implications of equilibrium business cycle models, in Thomas Cooley, eds. Frontiers of Business Cycle Research. Princeton NJ: Princeton University Press.

Sloan, R. G., 1996, Do stock prices fully reflect information in accruals and cash flows about future earnings? Accounting Review 71: 289-315

Smith, C. W. Jr. 1977. Alternative Methods for Raising Capital. Journal of Financial Economics 5:273-307

Schmalensee, R., 1972, The Economics of Advertising, North-Holland, Amsterdam (1972).

Srinivasan, Shuba and Dominique M, Hanssens, 2008, Marketing and firm value: metrics, methods, findings and future directions, Journal of Marketing Research, forthcoming.

Summers, Lawrence H., Barry P. Bosworth, James Tobin, and Philip M. White, 1981,Taxation and corporate investment: A q-theory approach. Brookings Papers on Economic Activity, 1, 67-140

Tauchen, J., and R. Hussey. 1991. Quadrature-based methods for obtaining approximate solutions to nonlinear asset pricing models. Econometrica 59 (2): 371-396.

Telser, L.G. , 1962, Advertising and cigarettes, Journal of Political Economy 70, pp. 471499

Titman, Sheridan, K.C. John Wei, and Feixue Xie, 2003, Capital investments and stock returns, Journal of Financial and Quantitative Analysis 39: 677-700

Whited, Tony, 1994, Problems with Identifying Adjustment Costs from Regressions of Investment on Q, Economics Letters 46 (1994): 339-344

Wu, Jin (Ginger)., Lu Zhang and Frank Zhang, 2009, The q-theory approach to understanding the accrual anomaly, forthcoming, Journal of Accounting Research

Xing, Yuhang, 2009. Interpreting the value effect through the Q-theory: an empirical investigation. Review of Financial Studies, Forthcoming

Zhang, Lu, 2005. The value premium. Journal of Finance 60 (1), 67-103 


\section{A Numerical Algorithm}

To solve the model numerically, we use the value function iteration procedure to solve the firm's maximization problem. The value function and the optimal decision rule are solved on a grid in a discrete state space. We use a multi-grid algorithm in which the maximum number of points is 50 in each dimension. In each iteration we specify a grid of points for capital and inventory, respectively with upper bounds $\bar{k}$ and $\bar{n}$ that are large enough to be non-binding. The grids for capital and inventory stocks are constructed recursively, following McGrattan (1999), that is, $k_{i}=k_{i-1}+c_{k 1} \exp \left(c_{k 2}(i-2)\right)$, where $i=1, \ldots, 50$ is the index of grids points and $c_{k 1}$ and $c_{k 2}$ are two constants chosen to provide the desired number of grid points and two upper bounds $\bar{k}$ and $\bar{n}$, given two pre-specified lower bounds $\underline{\mathrm{k}}$ and $\underline{\mathrm{n}}$. The advantage of this recursive construction is that more grid points are assigned around $\bar{k}$ and $\bar{n}$, where the value function has most of its curvature.

The state variable $x$ has continuous support in the theoretical model, but it has to be transformed into discrete state space for the numerical implementation. The popular method of Tauchen and Hussey (1991) does not work well when the persistence level is above 0.9. Because both the aggregate and idiosyncratic profitability processes are highly persistent, we use the method described in Rouwenhorst (1995) for a quadrature of the Gaussian shocks. We use 5 grid points for the $x$ process and 7 grid points for the $z$ process. In all cases the results are robust to finer grids as well. Once the discrete state space is available, the conditional expectation can be carried out simply as a matrix multiplication. Linear interpolation is used extensively to obtain optimal investment and inventory investment which do not lie directly on the grid points. Finally, we use a simple discrete, global search routine in maximizing the firm's problem.

\section{B Data}

Following Fama and French (1993), we define book value of equity as the COMPUSTAT book value of common equity (data item 60) plus balance-sheet deferred taxes (data item 74) and investment tax credits (data item 208), minus the book value of preferred stock. Depending on availability, we use the redemption (data item 56), liquidation (data item 10), or par value (data item 130) of preferred stock. When data item 60 is not available, the liquidation value of common equity (data item 235) is used. COMPUSTAT data item 128 is used for capital investment, $i$; the net book value of property, plant, and equipment (data item 8 ) is used for the capital, $k$; data item 3 is used for inventories stock, $n$. We follow Hou and Robinson (2006) and Fama-French (2008) in defining the main variables that we use in our analysis.

BM: Book-to-market equity, the ratio of the book value of equity to the market value of equity. Market equity is price times shares outstanding at the end of December of t, from CRSP.

ADVG: net real advertising growth rate, the ratio of the change in the stock of advertising expenses from year t to year t-1, deflated by the CPI. 
SG: Sales growth rate, the ratio of the change in the sales (12) from year t to year t-1 to the sales in year t-1, deflated by the CPI.

SIZE: the price times shares outstanding at the end of June of year t, from CRSP. 


\section{Table 1 : Summary Statistics of Selected Variables}

This table reports summary statistics of firm level physical capital investment rate (IK), brand capital investment rate (IBK), labor growth ( $\Delta$ Labor) and real sales growth rate ( $\Delta$ Sales). The table reports mean, standard deviation (S.D.), first order autocorrelation (AC(1)), and the $10^{\text {th }}$ and $90^{\text {th }}$ percentile of selected variables as well as their correlations. Panel A reports the summary statistics of annual variables from real data, for the period July 1975 to December 2009. Panel B reports the summary statistics computed as averages from 100 samples of simulated data from the theoretical model, each with 3600 firms and 40 annual observations. The model is simulated at monthly frequency and the data is aggregated into annual.

Panel A: Data

\begin{tabular}{lrrrrrrrrr} 
& & & \multicolumn{3}{c}{ Percentile } & \multicolumn{3}{c}{ Correlations } \\
\cline { 6 - 10 } Variable & Mean & S.D. & $\mathrm{AC}(1)$ & $10^{\text {th }}$ & $90^{\text {th }}$ & IK & IBK & $\Delta$ Labor & $\Delta$ Sales \\
\hline IK & 0.33 & 0.25 & 0.21 & 0.09 & 0.66 & 1 & 0.19 & 0.35 & 0.30 \\
IBK & 0.64 & 0.32 & 0.18 & 0.34 & 0.96 & 0.19 & 1 & 0.21 & 0.29 \\
$\Delta$ Labor & 0.09 & 0.22 & 0.04 & -0.11 & 0.32 & 0.35 & 0.21 & 1 & 0.49 \\
$\Delta$ Sales & 0.09 & 0.19 & 0.15 & -0.11 & 0.33 & 0.30 & 0.29 & 0.49 & 1 \\
\hline
\end{tabular}

Panel B: Model

\begin{tabular}{lrrrrrrrrr} 
& & & \multicolumn{3}{c}{ Percentile } & \multicolumn{3}{c}{ Correlations } \\
\cline { 6 - 10 } Variable & Mean & S.D. & AC $(1)$ & $10^{\text {th }}$ & $90^{\text {th }}$ & IK & IBK & $\Delta$ Labor & $\Delta$ Sales \\
\hline IK & 0.16 & 0.35 & 0.37 & -0.13 & 0.56 & 1 & 0.89 & 0.54 & 0.55 \\
IBK & 0.54 & 0.35 & 0.27 & 0.16 & 0.99 & 0.89 & 1 & 0.69 & 0.70 \\
$\Delta$ Labor & 0.05 & 0.34 & 0.05 & -0.36 & 0.54 & 0.54 & 0.69 & 1 & 0.99 \\
$\Delta$ Sales & 0.05 & 0.34 & 0.03 & -0.35 & 0.52 & 0.55 & 0.70 & 0.99 & 1 \\
\hline
\end{tabular}




\section{Table 2 : Calibration}

This table presents the calibrated parameter values used to simulate the model.

\begin{tabular}{lcc}
\multicolumn{1}{c}{ Parameter } & Symbol & Value \\
\hline Technology & $\alpha$ & 0.36 \\
Elasticity of output with respect to capital & $\gamma$ & 0.20 \\
Elasticity of price with respect to brand capital & $\varepsilon$ & 2 \\
Price elasticity of demand & $\delta_{k}$ & 0.01 \\
Rate of depreciation for physical capital & $\delta_{b}$ & $0.50 / 12$ \\
Rate of depreciation for brand capital & $c_{+}^{k}$ & 1 \\
Upward physical capital adjustment cost & $c_{-}^{k}$ & 10 \\
Downward physical capital adjustment cost & $c_{b}$ & 0.20 \\
Slope parameter in brand capital adjustment cost & $f$ & 0.145 \\
Fixed production cost & $\lambda_{0}$ & .005 \\
Fixed external financing cost & $\lambda_{1}$ & .01 \\
Proportional financing cost & & \\
& & \\
Stochastic Processes & $\lambda$ & 0.02 \\
Multiplicative coefficient on wage rate process & $\omega$ & 0.1 \\
Sensitivity of the wage rate to aggregate productivity & $\rho_{x}$ & $0.95^{1 / 3}$ \\
Persistence coefficient of aggregate productivity & $\sigma_{x}$ & $0.007 / 3$ \\
Conditional volatility of aggregate productivity & $\rho_{z}$ & 0.97 \\
Persistence coefficient of firm-specific productivity & $\sigma_{z}$ & 0.10 \\
Conditional volatility of firm-specific productivity & $\beta$ & 0.994 \\
Time-preference coefficient & $\gamma_{0}$ & 50 \\
Constant price of risk & $\gamma_{1}$ & -1000 \\
Time-varying price of risk & &
\end{tabular}




\section{Table 3 : Investment in Brand Capital Portfolios}

This table reports the time-series averages of characteristics of five portfolios sorted on investment in brand capital (IBK) in the real data (Data) and in 100 samples of simulated data from the theoretical model, each with 3600 firms and 40 annual observations (Model). Panel A reports the portfolio level mean excess return (per annum and in percentage) and corresponding heteroscedasticity-and-autocorrelation-consistent t-statistic. Panel B reports the average investment in brand capital portfolio average excess returns (per annum and in percentage) in the three years prior to portfolio formation, and one year, two years and three years after portfolio formation. Panel $\mathrm{C}$ reports averages of accounting variables measured at the time of the portfolio formation. We use medians as measures of portfolio characteristics. IK is the physical capital investment rate, IBK is the brand capital investment rate, $\Delta$ Labor is the employees growth rate, $\Delta$ Sales is the real sales growth, Book-to-Market is the ratio of book-equity to market-equity, Size is market equity. The sample for the real data is from July 1975 to December 2009.

\begin{tabular}{|c|c|c|c|c|c|c|}
\hline Portfolio & Low & 2 & 3 & 4 & High & H-L \\
\hline & \multicolumn{6}{|c|}{ Panel A: Excess Returns } \\
\hline \multicolumn{7}{|c|}{ - } \\
\hline Ret & 14.30 & 12.90 & 12.20 & 10.03 & 7.40 & -6.90 \\
\hline$[t]$ & 2.85 & 3.26 & 3.33 & 2.53 & 1.68 & -3.92 \\
\hline \multicolumn{7}{|l|}{ Model } \\
\hline$\overline{\text { Ret }}$ & 17.87 & 18.46 & 14.58 & 14.29 & 12.22 & -5.65 \\
\hline$[t]$ & 16.67 & 11.27 & 20.21 & 20.64 & 21.81 & -6.86 \\
\hline \multirow{2}{*}{\multicolumn{7}{|c|}{$\begin{array}{c}\text { Panel B: Excess Returns in Year Before (-) } \\
\text { and After }(+) \text { Portfolio Formation }\end{array}$}} \\
\hline & & & & & & \\
\hline Year -3 to -1 & 10.80 & 11.22 & 12.23 & 14.09 & 19.21 & 8.41 \\
\hline Year +1 & 14.30 & 12.90 & 12.20 & 10.03 & 7.40 & -6.90 \\
\hline Year +2 & 16.97 & 15.64 & 15.07 & 13.60 & 13.00 & -3.97 \\
\hline Year +3 & 16.63 & 16.38 & 15.45 & 13.94 & 13.00 & -3.63 \\
\hline \multicolumn{7}{|l|}{ Model } \\
\hline Year -3 to -1 & 4.69 & 7.11 & 11.91 & 21.19 & 31.02 & 26.32 \\
\hline Year +1 & 17.87 & 18.46 & 14.58 & 14.29 & 12.22 & -5.65 \\
\hline Year +2 & 18.19 & 18.25 & 14.81 & 14.33 & 12.75 & -5.44 \\
\hline Year +3 & 17.81 & 17.22 & 14.9 & 14.41 & 13.06 & -4.75 \\
\hline
\end{tabular}


Table 3 : Investment in Brand Capital Portfolios (cont.)

\begin{tabular}{lrrrrrr}
\hline Portfolio & Low & 2 & 3 & 4 & High & H-L \\
\hline \multicolumn{7}{c}{ Panel C: Accounting } \\
Data & \multicolumn{7}{c}{ Characteristics } \\
\hline IK & 0.17 & 0.19 & 0.21 & 0.25 & 0.31 & 0.14 \\
IBK & 0.30 & 0.47 & 0.57 & 0.68 & 1.07 & 0.77 \\
$\Delta$ Labor & -0.02 & 0.01 & 0.02 & 0.05 & 0.10 & 0.12 \\
$\Delta$ Sales & -0.01 & 0.02 & 0.04 & 0.09 & 0.15 & 0.16 \\
Book-to-Market & 0.82 & 0.82 & 0.76 & 0.68 & 0.62 & -0.20 \\
Size & 3.53 & 4.50 & 5.08 & 5.09 & 4.56 & 1.03 \\
& & & & & & \\
Model & & & & & & \\
\hline IK & 0.00 & 0.08 & 0.15 & 0.20 & 0.35 & 0.35 \\
IBK & 0.24 & 0.45 & 0.52 & 0.56 & 0.88 & 0.64 \\
$\Delta$ Labor & -0.11 & -0.03 & 0.00 & 0.02 & 0.21 & 0.32 \\
$\Delta$ Sales & -0.11 & -0.04 & 0.00 & 0.03 & 0.21 & 0.32 \\
Book-to-Market & 0.79 & 0.66 & 0.56 & 0.53 & 0.47 & -0.32 \\
Size & 17.99 & 17.49 & 20.91 & 23.41 & 28.34 & 10.35 \\
\hline
\end{tabular}




\section{Table 4 : Portfolio Transition Probabilities}

This table reports the transition probabilities across five portfolios sorted on brand capital investment rates (IBK) in the real data (Panel A) for the period July 1975 to December 2009, and averages from 100 samples of simulated data from the theoretical model, each with 3600 firms and 40 annual observations (Panel B).

Panel A: Data

\begin{tabular}{llrrrrrr} 
& & \multicolumn{9}{c}{ Sort $(\mathrm{t})$} \\
& Portfolio & Low & \multicolumn{1}{c}{2} & \multicolumn{1}{c}{3} & \multicolumn{1}{c}{4} & High & Exit \\
\hline & Low & 41.54 & 15.58 & 7.05 & 5.39 & 6.94 & 23.50 \\
& 2 & 15.78 & 31.14 & 19.70 & 10.69 & 6.59 & 16.10 \\
Sort (t-1) & 3 & 8.99 & 21.56 & 30.24 & 18.41 & 8.00 & 12.81 \\
& 4 & 7.25 & 12.93 & 22.70 & 29.80 & 14.29 & 13.03 \\
& High & 6.88 & 6.09 & 9.43 & 23.14 & 39.29 & 15.16 \\
\hline
\end{tabular}

Panel B: Model

\begin{tabular}{llrrrrrr} 
& & \multicolumn{9}{c}{ Sort $(\mathrm{t})$} \\
& Portfolio & Low & \multicolumn{1}{c}{2} & \multicolumn{1}{c}{3} & \multicolumn{1}{c}{4} & High & \\
\hline \multirow{4}{*}{ Sort (t-1) $)$} & Low & 39.44 & 37.29 & 2.31 & 5.38 & 15.58 & - \\
& 2 & 16.78 & 36.31 & 20.11 & 8.00 & 18.80 & - \\
& 3 & 13.16 & 9.62 & 53.18 & 11.52 & 12.52 & - \\
& 4 & 15.82 & 9.94 & 21.40 & 38.56 & 14.27 & - \\
& High & 14.80 & 6.85 & 3.00 & 36.53 & 38.82 & - \\
\hline
\end{tabular}




\section{Table 5 : Other Brand Capital Portfolios}

This table report the time-series portfolio level mean excess return (per annum and in percentage) and corresponding heteroscedasticity-and-autocorrelation-consistent t-statistic, of five portfolios sorted on advertising expenditures growth and five portfolios sorted on brand capital to physical capital ratio. The table reports the time-series average in the real data (Data) for the period July 1975 to December 2009, as well as averages from 100 samples of simulated data from the theoretical model, each with 3600 firms and 40 annual observations (Model).

\begin{tabular}{|c|c|c|c|c|c|c|}
\hline Portfolic & Low & 2 & 3 & 4 & High & $\mathrm{H}-\mathrm{L}$ \\
\hline Data & \multicolumn{6}{|c|}{ Advertising Growth Portfolios } \\
\hline Ret & 14.77 & 13.19 & 11.53 & 10.49 & 8.42 & -6.35 \\
\hline [t] & 2.98 & 3.33 & 3.23 & 2.72 & 1.86 & -3.85 \\
\hline \multicolumn{7}{|l|}{ Model } \\
\hline Ret & 17.81 & 18.51 & 14.59 & 14.30 & 12.21 & -5.60 \\
\hline [t] & 16.62 & 11.34 & 20.09 & 20.78 & 21.74 & -6.82 \\
\hline \multicolumn{7}{|c|}{ Brand Capital to Labor Ratio Portfolios } \\
\hline Ret & 9.08 & 10.98 & 10.81 & 12.83 & 13.12 & 4.04 \\
\hline$[\mathrm{t}]$ & 2.14 & 2.58 & 2.65 & 2.93 & 3.28 & 2.58 \\
\hline \multicolumn{7}{|l|}{ Model } \\
\hline Ret & 11.08 & 12.25 & 13.62 & 20.39 & 19.79 & 8.71 \\
\hline [t] & 21.55 & 21.53 & 20.40 & 12.83 & 14.82 & 7.16 \\
\hline
\end{tabular}




\section{Table 6 : Brand Capital and Firm Market Value}

This table reports estimates of a Tobin q regressions on firms' level brand capital to capital ratio, and other firm characteristics. The variables are defined as follows: Brand Capital/K is the brand capital to physical ratio, Ret is the past one year cumulated stock return, Size is the previous year December firm market capitalization. The regression includes both year and firm fixed effects when noted. Standard errors are robust to heteroscedasticity and clustered by firm and year. All data are standardized to have mean zero and unit variance.

\begin{tabular}{|c|c|c|c|c|c|c|}
\hline & \multicolumn{6}{|c|}{ Dependent Variable $\log (Q(t))$} \\
\hline & \multicolumn{3}{|c|}{ Data } & \multicolumn{3}{|c|}{ Model } \\
\hline & (i) & (ii) & (iv) & (i) & (ii) & (iv) \\
\hline \multirow[t]{2}{*}{ Brand Capital/K(t) } & 0.077 & 0.049 & 0.103 & & & \\
\hline & 5.635 & 3.977 & 7.474 & & & \\
\hline \multirow[t]{2}{*}{$\operatorname{Ret}(\mathrm{t}-1)$} & & & 0.139 & & & \\
\hline & & & 8.535 & & & \\
\hline \multirow[t]{2}{*}{$\operatorname{Size}(\mathrm{t}-1)$} & & & 0.310 & & & \\
\hline & & & 13.001 & & & \\
\hline $\mathrm{N}$ & 29695 & 28876 & 24640 & & & \\
\hline $\mathrm{R} 2$ & 0.583 & 0.233 & 12.648 & & & \\
\hline Time effects & Yes & Yes & Yes & $\overline{\text { Yes }}$ & $\overline{\text { Yes }}$ & $\overline{\text { Yes }}$ \\
\hline Firm effects & No & Yes & No & No & Yes & No \\
\hline
\end{tabular}




\section{Figure 1 : Brand Capital and Physical Investment Impulse Response and SEOs}

This figure plots the impulse response of investment in brand capital (IBK), investment in physical capital (IK) and external finance (Fin), to a one percentage increase in the aggregate productivity shock. External finance is defined as negative dividends. Positive external finance is interpreted as a seasoned equity offering (SEO). The frequency of the data is monthly.

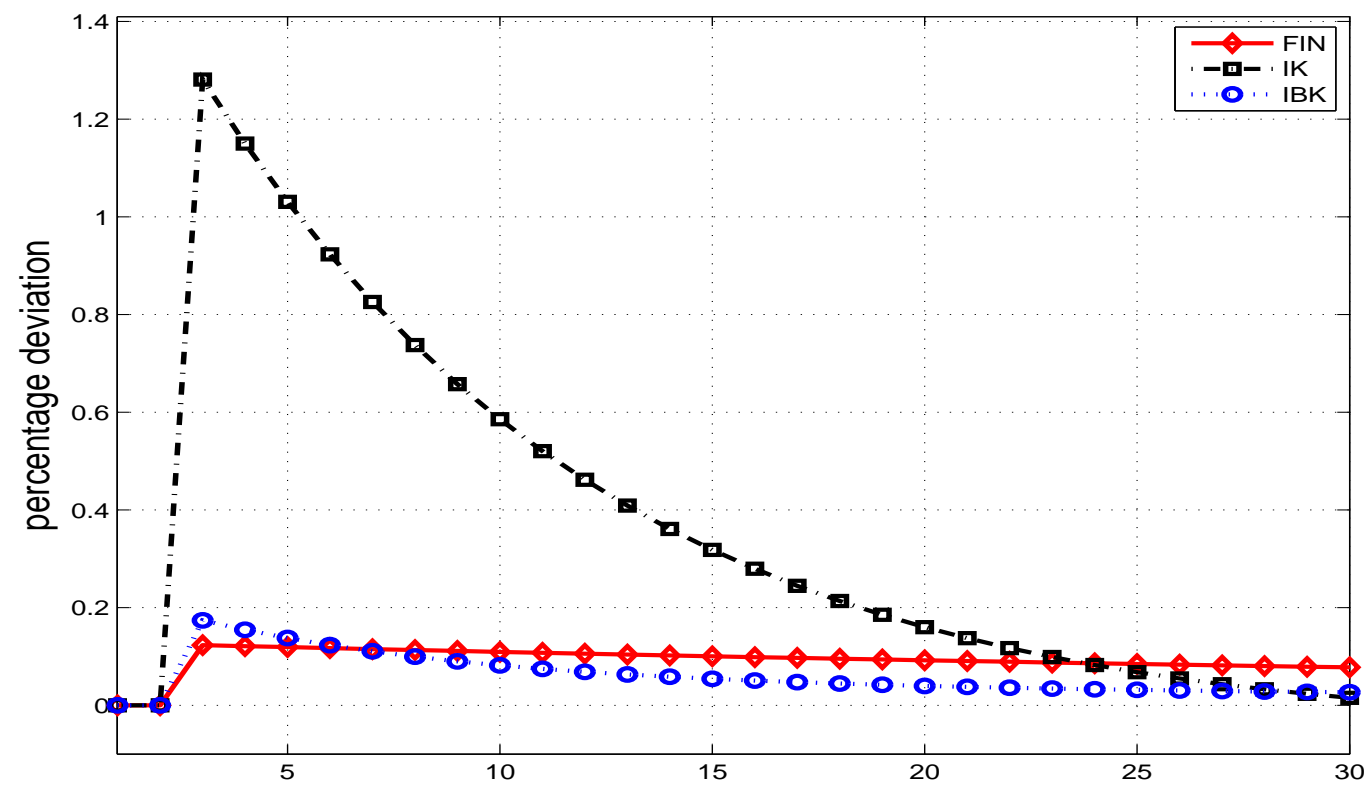

